\title{
THE ONSET OF PROGESTERONE SECRETION DURING PREGNANCY IN THE MOUSE
}

\author{
C. A. FINN AND L. MARTIN \\ Department of Physiology, The Royal Veterinary College, London, N.W.1, and \\ Department of Hormone Physiology, Imperial Cancer Research Fund, Lincoln's Inn Fields, \\ London, W.C.1
}

(Received 10th December 1970)

In a recent paper, it was postulated that the secretion of progesterone from the ovary during early pregnancy in the mouse does not start until the 3rd day after the finding of the copulation plug (Finn \& Martin, 1969). This was based on the observation that, if pregnant mice were ovariectomized a few hours after mating and given progesterone before Day 3 , the mitosis which normally occurs in the uterine glands and to a lesser extent in the luminal epithelium on Day 3 (Finn \& Martin, 1967) is suppressed.

The object of the present work was to see whether exogenous progesterone given to entire pregnant mice before Day 3 would cause a similar change in the pattern of uterine mitosis on Day 3 and, if so, to determine whether prolactin given early in pregnancy would cause the early release of progesterone from the ovary.

In the first experiment, pregnant mice were injected subcutaneously with $1 \mathrm{mg}$ progesterone on Days 1 and 2 and killed on Day 3, $2 \mathrm{hr}$ after a subcutaneous injection of $0 \cdot 1 \mathrm{mg}$ Colcemid. The mice were kept under controlled lighting conditions with a dark period of $8 \mathrm{hr}$ ending at noon. Inspection for vaginal plugs took place in the afternoon and the day on which they were found was called Day 1 of pregnancy. The uteri were fixed in Bouin's fluid and the number of cells undergoing mitosis in the various uterine tissues counted in one randomly picked histological section (Finn \& Martin, 1969). The results are shown in Table 1 (Groups 1 and 2). The number of cells in mitosis in the glandular and luminal epithelia of the progesterone-treated animals was considerably less than in the controls. In the next experiment, a single injection of progesterone ( $1 \mathrm{mg}$ or $400 \mu \mathrm{g}$ ) was given on Day 2 and the animals then treated as before. Again, there was suppression of epithelial mitosis, especially in the glands.

From these results, it was concluded that the suppression of epithelial mitosis would provide a guide to the secretion of progesterone by the ovary and thus a means of determining whether the corpus luteum is able to respond to prolactin and secrete progesterone before Day 3 of pregnancy.

A group of pregnant mice was given three injections of 12.5 i.u. prolactin, the first a few hours after mating on Day 1 and the remaining two on Day 2. 
This dose of prolactin was found to be effective in preventing the anti-implantation effects of D-6-methyl-8 cyanomethylergoline, a drug which inhibits the release of prolactin and thus the secretion of progesterone in mice (Mantle \& Finn, 1971). There was not a significant difference in the pattern of mitosis between the prolactin-treated and the control animals, indicating that the prolactin had not stimulated the release of effective amounts of progesterone on Day 2.

These results suggest, either that the corpus luteum is not sufficiently developed to secrete progesterone before Day 3, that some other factor is involved in the initiation of secretion or that there is a time lag of up to $48 \mathrm{hr}$ between prolactin reaching the ovary and the secretion of progesterone.

\section{TABLE 1}

THE EFFECT OF ADMINISTRATION OF EXOGENOUS PROGESTERONE OR PROLACTIN TO MICE ON DAYS 1 AND 2 OF PREGNANGY ON THE PATTERN OF CELL DIVISION IN THE UTERUS ON DAY 3

\begin{tabular}{|c|c|c|c|c|}
\hline \multirow{2}{*}{ Treatment } & \multirow{2}{*}{$\begin{array}{c}\text { No. of } \\
\text { mice }\end{array}$} & \multicolumn{3}{|c|}{ Mean number of mitoses $\pm S . E$. } \\
\hline & & Epith & elium & Stroma \\
\hline $\begin{array}{l}\text { Control } \\
1 \mathrm{mg} \text { progesterone on Days } 1 \text { and } 2 \\
1 \mathrm{mg} \text { progesterone on Day } 2 \\
400 \mu \mathrm{g} \text { progesterone on Day } 2 \\
12 \cdot 5 \text { i.u. prolactin on Days } 1 \text { and } 2\end{array}$ & $\begin{array}{l}5 \\
5 \\
4 \\
5 \\
8\end{array}$ & $\begin{array}{l}9 \cdot 8 \pm 2 \cdot 2 \\
0 \cdot 8 \pm 0 \cdot 4^{* * *} \\
3 \cdot 5 \pm 1 \cdot 2^{*} \\
2 \cdot 4 \pm 0 \cdot 7^{*} \\
9 \cdot 0 \pm 1 \cdot 4^{\text {N.s. }}\end{array}$ & $\begin{array}{c}30 \cdot 8 \pm 5 \cdot 6 \\
0 \\
2 \cdot 8 \pm 1 \cdot 3^{* *} \\
6 \cdot 4 \pm 2 \cdot 0^{* *} \\
26 \cdot 0 \pm 4 \cdot 4^{\text {N.s. }}\end{array}$ & $\begin{array}{l}0 \cdot 4 \pm 0 \cdot 4 \\
3 \cdot 0 \pm 1 \cdot 0^{\text {N.s. }} \\
2 \cdot 8 \pm 1 \cdot 5^{\text {N.s. }} \\
2 \cdot 6 \pm 0 \cdot 9^{*} \\
1 \cdot 5 \pm 1 \cdot 1^{\text {N.s. }}\end{array}$ \\
\hline
\end{tabular}

${ }^{*} P<0.05,{ }^{* *} P<0.01$, significantly different from equivalent control group.

In view of the marked suppression of mitosis in the uterine glands in mice treated with progesterone on Days 1 and 2, it is rather surprising that such treatment does not affect the course of pregnancy. This was shown earlier by Martin (1963) and was confirmed in the present study by allowing a group of five mice, which had been treated on Days 1 and 2 of pregnancy with $1 \mathrm{mg}$ progesterone to continue to term. All five had normal litters. This raises the interesting question of the significance of glandular proliferation on Day 3 and of the function of the uterine glands in mice.

We would like to thank Mrs G. Park and Mr J. Lewin for technical assistance.

\section{REFERENCES}

Finn, C. A. \& Martin, L. (1967) Patterns of cell division in the mouse uterus during early pregnancy. 7. Endocr. 39, 593.

FinN, G. A. \& MARTIN, L. (1969) Hormone secretion during early pregnancy in the mouse. F. Endocr. $45,57$.

MantLe, P. G. \& FinN, C. A. (1971) Investigations on the mode of action of D-6-methyl-8-cyanomethylergoline in suppressing pregnancy in the mouse. F. Reprod. Fert. 24, 441.

MARTIN, L. (1963) Interactions between oestradiol and progestogens in the uterus of the mouse. 7. Endocr. 26, 31. 